
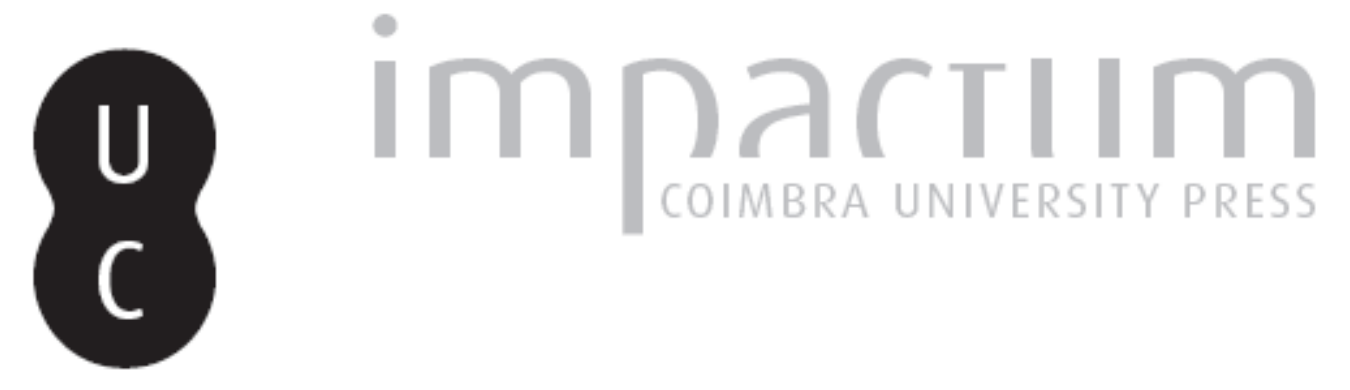

\title{
Eburobrittium e suas epígrafes singulares
}

Autor(es): $\quad$ Encarnação, José d'; Moreira, José Beleza

Publicado por: Faculdade de Letras da Universidade de Coimbra

URL persistente:

URI:http://hdl.handle.net/10316.2/37859

DOI:

DOI:http://dx.doi.org/10.14195/1647-8657_49_3

Accessed : $\quad$ 26-Apr-2023 12:52:52

A navegação consulta e descarregamento dos títulos inseridos nas Bibliotecas Digitais UC Digitalis, UC Pombalina e UC Impactum, pressupõem a aceitação plena e sem reservas dos Termos e Condições de Uso destas Bibliotecas Digitais, disponíveis em https://digitalis.uc.pt/pt-pt/termos.

Conforme exposto nos referidos Termos e Condições de Uso, o descarregamento de títulos de acesso restrito requer uma licença válida de autorização devendo o utilizador aceder ao(s) documento(s) a partir de um endereço de IP da instituição detentora da supramencionada licença.

Ao utilizador é apenas permitido o descarregamento para uso pessoal, pelo que o emprego do(s) título(s) descarregado(s) para outro fim, designadamente comercial, carece de autorização do respetivo autor ou editor da obra.

Na medida em que todas as obras da UC Digitalis se encontram protegidas pelo Código do Direito de Autor e Direitos Conexos e demais legislação aplicável, toda a cópia, parcial ou total, deste documento, nos casos em que é legalmente admitida, deverá conter ou fazer-se acompanhar por este aviso.

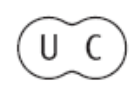


CONIMBRIGA

C)

CN N N

INSTITUTO DE ARQUEOLOGIA

VOLUME XLIX • 2010

FACULDADE DE LETRAS 
José D'ENCARNAÇÃO

Professor Catedrático aposentado da Faculdade de Letras de Coimbra

Membro do Centro de Estudos Arqueológicos das Universidades de Coimbra e Porto

José BelEZA MOREIRA

Mestre em Arqueologia pela Universidade de Coimbra

\section{EBUROBRITTIUM E AS SUAS EPÍGRAFES SINGULARES}

"Conimbriga" XLIX (2010) p. 41-67

Resumo: Apesar de algumas das inscrições eburobricienses já terem sido dadas a conhecer, nunca delas se fez o estudo epigráfico propriamente dito nem delas se retiraram as informações de conjunto que a sua análise possibilita. Esse, o intuito deste artigo.

PALAVRAS-CHAVE: Eburobrittium, epigrafia, Constâncio Cloro, grafitos.

RÉSUMÉ: On a déjà fait connaître quelques inscriptions trouvées à Eburobrittium, civitas et port de la Lusitania occidentale. Néanmoins, on n'avait jamais fait leur étude d'ensemble, pour en retirer des renseignements historiques que seulement cette analyse permet. C'est celui-là le but de cet article.

Palavras-CHave: Eburobrittium, épigraphie, Constance Chlore, graffites.

Conimbriga, 49 (2010) 41-67 
(Página deixada propositadamente em branco) 


\section{EBUROBRITTIUM \\ E AS SUAS EPÍGRAFES SINGULARES}

\section{Introdução}

Depois de muitos anos de hesitações (vide, por exemplo, GARCIA 1971), já se sabe onde é Eburobrittium.

Cidade que desempenhou, sem dúvida, importante papel desde os primórdios da chegada dos Romanos ao Ocidente peninsular, designadamente como abrigado porto por onde se escoavam os produtos agrícolas de uma zona sempre fértil e, também, o que resultava das explorações mineiras, Eburobrittium vem citada nos livros mais antigos; assim, já Luís Marinho de Azevedo (1753) a ela se refere (cf. Encarnação 2001-2002, 391-392).

A investigação levada a cabo junto a Óbidos (cf. MOREIRA 2002) acabou com todas as hesitações e a localização da cidade romana veio provar como havia razão em dar-lhe importância no contexto da época romana peninsular.

Depois dessa publicação, que fez o ponto da situação do que até então se conhecia da cidade e deu conta dos resultados das campanhas de escavações aí efectuadas, outras campanhas naturalmente se fizeram; no entanto, no que concerne à cidade romana pouco se adiantou, pois apenas se ampliou a área de dois edifícios, cuja cronologia se pode enquadrar entre os séculos XIV/XV e XVIII/XIX.

No que respeita aos monumentos epigráficos encontrados, houve ensejo em 2005, de dar a conhecer os mais significativos, chamando a atenção para a relevância que tinham no contexto da época romana no litoral da Lusitânia; contudo, nunca fizemos um estudo epigráfico propriamente dito dessas inscrições. A isso nos propomos agora, sublinhando, no final, os dados mais salientes que se nos apresentaram à análise.

Conimbriga, 49 (2010) 41-67 


\section{Corpus das inscrições}

1 - Dedicatória a Constâncio Cloro [Fig. 1]

Fragmento de placa, de calcário, identificado, durante a campanha de escavações de 1997, no corredor das termas e em nível de entulhamento (quadrado IV-223) ${ }^{1}$. Faces lateral e posterior alisadas.

Dimensões: $22 / 27$ x 46 x 23 .

$\mathrm{D}($ omino $) \cdot \mathrm{N}($ ostro $) /$ FLAVIO / [...]

Ao nosso senhor Flávio...

Altura das letras: 1. 1: D: 6,5; N: 5,3/6,0; 1. 2: F: 6,6 (as restantes letras encontram-se cortadas). Espaços: $1: 7 ; 2: 3,5$.

Gravação feita com goiva, não sendo possível avaliar do cuidado eventualmente posto na paginação. $\mathrm{O}$ facto, porém, de a 1.1 apenas ter as siglas leva a crer que estamos perante uma inscrição que se estenderia ao alto, e, sendo assim, a 1. 2 poderia estar completa. A forma dos caracteres não se afasta do que se conhece de epígrafes deste tipo e desta cronologia, para mais gravados num material rugoso, o que obrigou ao uso não do buril mas da goiva, como se disse, para obter um sulco arredondado. Assim, há tendência para algum 'cursivismo' nesse traçado, visível no F (o ductus aponta para se ter gravado, de cima para baixo, a barra superior e a haste vertical), no arredondamento superior do A, na ampla abertura do $\mathrm{V}$ e, também, do $\mathrm{N}$, no ovalado do $\mathrm{O}$ e, até, na falta de precisão geométrica do $\mathrm{D}$ inicial.

Escusado será dizer que se reveste de elevado interesse histórico a presença de uma dedicatória imperial, com alguma hipótese de se poder referir a um edifício de espaço público, onde estaria embutida (partindo do princípio de que a reutilização a não deformou consideravelmente). Mostra que a cidade se manteve activa durante bastante tempo e a população ligada ao poder central. $\mathrm{Na}$ verdade, a designação dos imperadores como domini nostri - a chamada 'dominização do poder' (TURCAN 1978 1002-1003) - figura oficialmente nas epígrafes a partir do reinado de Aureliano (270-275), ${ }^{2}$ como forma de legitimar o poder;

1 MOREIRA 2002, 97 (foto na p. 98).

2 Cagnat (1914, 233-234, nota 1) coloca esse costume um tudo-nada mais tarde, «a partir de Diocleciano» (284-305), acrescentando: «titre que Sévère Alexandre

Conimbriga, 49 (2010) 41-67 
e os súbditos (não os cidadãos) amiúde se proclamam devoti numini maiestatique eius, «devotos do seu númen e da sua majestade». ${ }^{3}$ Aliás, num momento em que nenhuma outra legitimação se poderia invocar, passa, por exemplo, a figurar nas moedas a deusa Vitória e a legenda VICTORIA AVGVSTI, índice da graça divina de que o soberano estava dotado, como fonte de felicidade para os homens.

A partir de Constâncio Cloro (292-306), boa parte dos imperadores pertencem à gens Flavia e incluem esse nomen na sua identificação oficial; por esse motivo, torna-se difícil garantir, à partida, a atribuição desta dedicatória a um deles em particular. Inclinar-nos-íamos, porém, a optar exactamente pelo primeiro, atendendo às circunstâncias que o levaram ao poder, que determinaram um movimento de apoio por parte das populações provinciais - e Eburobrittium, dado o seu poder económico e importância estratégica, não poderia ter ficado atrás. Veja-se que - não muito longe - a civitas Aeminiensis também não hesitou em mandar colocar no seu forum uma placa em sua honra (CIL II 5239; ENCARNAÇÃO 1979 173-176), acentuando que, at aucmentum [sic] Reipublicae natus, o príncipe era dilectus, muito benquisto, pois, pelos Eminienses; e, em Conimbriga, o miliário dedicado a este imperador (Fouilles II $\mathrm{n}^{\circ} 103$, p. 118), datável, como o anterior, dos anos 305 ou 306, pode ser encarado como marco a assinalar a construção das muralhas desta e daquela cidade: «Il est séduisant de penser que c'est sous cet empereur que les murailles des deux villes ont été édifiées», escrevem os autores de Fouilles II, não sem, antes, terem sublinhado a relevância da «activité de cet empereur dans la partie occidentale de la Péninsule Ibérique».

Permita-se-nos, pois, que façamos nossas as suas palavras: é, na verdade, sedutor pensar que esta placa - passível de, no seu contexto original ter estado nas termas ou, mais verosimilmente, no forum, que lhe fica a 25,80 metros a sul - se integra na referida série de monumentos epigráficos erigidos para mostrar fidelidade e apreço a Constâncio Cloro, por ocasião da sua nomeação como Augustus, em 305, após a abdicação de Diocleciano.

semble avoir été le premier à recevoir»; temos, portanto, documentação que contraria hoje essa hipótese.

3 Cf. CIL II 1171, de Sevilha: D(omino) n(ostro) / Flavio Valerio / Constantio / nobiliss(imo) Caes(ari) / Resp(ublica) Hispal(ensis) / devota numini maiestatique eius.

Conimbriga, 49 (2010) 41-67 


\section{2 - Estela funerária de um escravo [Fig. 2]}

Estela funerária, de pedra arenítica, identificada quando se procedeu, em 2001, ao levantamento de uma conduta associada a uma construção da época medieval ou moderna. Cantos superiores arredondados.

Dimensões: 165 x 60 x 15,5.

\section{EPAPHRA FELIX / THESMVS - PVBL(ici) / FAVSTO · CONSER(vo)}

Epafra, Félix, Tesmo, públicos - a Fausto, conservo.

Altura das letras: 1. 1: 7/7,5; 1. 2: $7.3(\mathrm{M}=7 ; \mathrm{B}=7,5) ; 1.3: 7 / 7,6$. Espaços: $1: 25,5 ; 2: 2 ; 3: 3 ; 4: 106$.

ENCARNAÇÃO 2003 169-170; AE 2003, 858; ENCARNAÇÃO \& MOREIRA 2005, 132; HEp 13, 2007, nº 995.

Apesar de alguma irregularidade na altura das letras, o texto está bem paginado, com alinhamento à esquerda e à direita, ocupando um espaço legível à altura dos olhos.

Caracteres esguios, bem desenhados com recurso a régua: note-se a verticalidade das hastes e o carácter uniforme das barras, muito direitas e curtas. De salientar, do ponto de vista paleográfico: a regularidade dos EE; P não fechado e de pança diminuta; aliás, a partir do $\mathrm{P}$ se gravou o $\mathrm{R}$ - de perna bem lançada para diante - e mesmo o $\mathrm{B}$, que é assimétrico; $\mathrm{S}$ alongado, levemente inclinado para diante; $\mathrm{O}$ bem circular; $\mathrm{N}$ e M a denotarem alguma dificuldade no seu traçado por parte do lapicida; A de travessão oblíquo na 1.1 e horizontal na 1. 3; X bem simétrico.

Pela paleografia e pela simplicidade do texto, datá-lo-íamos, pois, da $1^{\text {a }}$ metade do século I, senão mesmo de finais do I a. C.

Houve ensejo de se fazer referência a este texto (Encarnação 2003 167-169), no âmbito de uma reflexão sobre a ambiguidade que pode resultar de uma paginação intencionalmente feita de molde a possibilitar duas leituras da epígrafe - estratagema amiúde usado, ainda hoje, pelos publicitários, quando recorrem a maquetizações ou a palavras que dão azo a um duplo sentido.

Neste caso, o problema põe-se em relação às duas únicas palavras que estão em abreviatura: PVBL e CONSER. Afigurou-se-nos mais lógico relacionar a primeira com os três nomes que a antecediam e a segunda ao quarto nome. Mas - claro! - mesmo para o leitor de então, 
PVBL poderia interpretar-se como PVBL(ice), 'publicamente' ou, ainda, como PVBL(icio), sendo, então, uma qualificação de Faustus, eventualmente tornado liberto público. Na verdade, interpretadas como pensamos que o devam ser, essas palavras assinalam o carácter servil dos quatro personagens citados na epígrafe. Não será, porventura, um labéu de ignomínia, porque ser escravo público denunciaria, naturalmente, um estatuto com - apesar de tudo - algum prestígio, sendo certo que, mais tarde ou mais cedo, pelo seu comportamento ou pelo pecúlio acumulado, esses escravos poderiam vir a ser libertados. De resto, houve o cuidado também de não escrever a palavra ser(vi), subentendendo-a inteligentemente...

Aproveite-se para referir, a talhe de foice, que é a civitas Igaeditanorum o outro aglomerado populacional datável desses primórdios da época romana peninsular onde, na Lusitânia, se regista a presença de escravos públicos. Trata-se, neste caso, de uma referência indirecta, é certo, porque Flavius Ariston se apresenta como Igaeditanorum libertus, tal como Chryseros (cf. SÁ 2007, inscrições n ${ }^{\text {os }} 23$ e 10), o que implica que terão sido escravos públicos.

Ora, este facto denuncia - tanto para uma civitas como a dos Igeditanos como para uma cidade (de estatuto administrativo por ora desconhecido) como Eburobrittium - um relevo económico e social não despiciendo, sobre que importa reflectir.

O texto da epígrafe denota, por seu turno, um perfeito conhecimento das regras epigráficas e da identificação. Felix e Faustus, pela sua conotação 'positiva', de portadores de felicidade e de riqueza, constituem, na verdade, nomes muito adequados a escravos. Kajanto, além de referir a sua extrema frequência no conjunto do CIL (2021 testemunhos de Faustus, 5115 de Felix - p. 72), assinala, em primeiro lugar dentre quatro, esses «cognomina suggesting "good luck"», «which were comparatively frequent among slaves/freedmen» (ibidem). Mais uma prova, portanto, de que a população de Eburobrittium se encontrava bem dentro das regras onomásticas vigentes no mundo romano. Aliás, a utilização, em abreviatura, de palavras não muito correntes em epigrafia, como publicus e conservus, ${ }^{4}$ confirma esse nível cultural fora do comum.

4 Por curiosidade, consultámos, a este propósito, a base de dados dos monumentos epigráficos peninsulares - http://www.eda-bea.es/ - e apenas identificámos cinco testemunhos de conservus: em Braga, Sagunto, Tarragona e Aldaya (aqui, dois). Procurando servus publicus, apenas nos é indicada a cláusula da lex Irnitana que deles

Conimbriga, 49 (2010) 41-67 
Tal carácter de excepção se reflecte de igual modo na atribuição, a dois dos escravos, de nomes gregos verdadeiramente inusitados. De Epaphra, a dar crédito ao elenco recolhido por Abascal, só se conhecem mais dois exemplos (p. 352): o de Scribonius Epaprhas [sic] em Trício (CIL II 2896 = 5806) e o de Ephapra [sic], eventualmente servus Pacciorum, documentado em Écija; a dificuldade registada no modo de grafar o nome é, de facto, indício da raridade do seu uso. ${ }^{5}$ No que concerne a Thesmus, quiçá relacionável com o termo grego «thesmós», 'instituição', 'tradição', e que, por isso, poderá querer significar 'aquele que segue a tradição', é, segundo cremos, a primeira vez que se documenta na Península Ibérica.

Estamos, por conseguinte, mau grado a simplicidade do texto que ostenta, perante uma das epígrafes eburobricienses mais... eloquentes!

\section{3 - Fragmento de inscrição funerária ou honorifica [Fig. 3]}

Fragmento com inscrição funerária ou honorífica, de lioz rosada da região, identificado num monte de pedras, aquando do arranjo da área envolvente do prédio do Casal da Zambujeira (arredores de Óbidos), em data não determinável, mas anterior a 1998. Encontra-se na Casa de Campo de São Rafael, propriedade de Hernâni Pedras e Susana Castanheira. $^{6}$

É o facto de a espessura ser proporcionalmente grande que nos leva a hesitar na classificação tipológica do monumento. Não parece ser placa - não está alisada na parte posterior, mas apenas no lado esquerdo (à direita está partida) - e, por isso, poderá ser um cipo ou, mais provavelmente, uma estela do jeito das que são comuns na epigrafia olisiponense e de que o Museu Arqueológico de Odrinhas, em Sintra, guarda exemplares completos. Sendo assim, a hipótese de estarmos perante um texto de índole funerária afigura-se-nos provável.

Dimensões: $(42,5) \times(41) \times(30,5)$.

trata (registo ${ }^{\circ} 5058$ ) e a referência a Maternus, servus publicus meritus, mencionado numa epígrafe de Benatae (Jaén - registo $\mathrm{n}^{0} 5108$ dessa base de dados).

5 Em Roma, Solin (1982 324-326) assinalou um total de 107 testemunhos, dos quais 60 seguramente identificando escravos ou libertos. Já agora, diga-se que, em relação a Thesmus, esse mesmo autor registou (p. 1240) somente seis exemplos, três dos quais como nomes de escravos ou libertos.

6 Apesar de não proveniente do sítio arqueológico propriamente dito, é do seu ager e por isso a incluímos.

Conimbriga, 49 (2010) 41-67 
Campo epigráfico: 29,0 x 24.

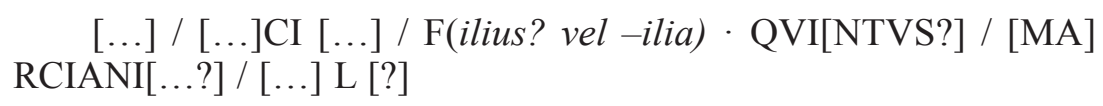

Altura das letras: 1.2 e 3: 7,5 ( $\mathrm{I}=6,5)$. Espaços: 2: 2; 3: 2,6/2; 4: 2,5 .

Caracteres classificáveis como capitais quadrados, com alguma tendência actuária, muito bem desenhados, em bisel - denotando, por isso, os meados do século I d. C. Os vértices são terminados com requinte; Q bem circular e de haste muito prolongada que quase toca o A da linha seguinte; $\mathrm{V}$ simétrico; $\mathrm{R}$ feito a partir do $\mathrm{P}$ (não chegando, pois, à haste vertical) de perna levemente ondulada; $\mathrm{C}$ circular, albergando o I no seu interior; A estreito, de barra subtil; $\mathrm{N}$ simétrico, afigurando-se-nos que poderá ostentar o nexo NI, a não ser que se trate de um rasgo feito posteriormente à gravação da inscrição.

CI poderá ser o final de um antropónimo masculino em genitivo (não é raro que esse caso seja usado na epigrafia funerária do extremo Ocidente da Lusitânia); o F da 1.2 não nos oferece dúvidas: antes dele viria o patronímico e seguir-se-lhe-ia o cognomen: Quinti será possível, ainda que o I esteja mais curto; a possibilidade de termos aí um L (que a fotografia leva a indiciar) é, quanto a nós, remota, porque não faria sentido; talvez se possa intuir também o arranque inferior da haste do $\mathrm{N}$ seguinte, no esborcelamento que a pedra sofreu.

$\mathrm{Na}$ actual 1. 3, a reconstituição [MAR]CIANI não sofrerá contestação, sendo este um cognomen outras vezes documentado na Lusitânia, mormente na sua zona ocidental, como se vê no Atlas (mapa 191, p. 228). Aliás, há o registo, em Alfeizerão (CIL II 357) de uma Iulia Marciana e Vasco Mantas (1982, mapa II, p. 96-97) acentua precisamente essa ocorrência.

Na última linha, pode existir um ponto de separação sensivelmente na direcção do vértice inferior do A da linha anterior, mas não é seguro; e a haste de que nos resta um troço bem vertical pode ser de um I ou de um H. Esperaríamos aí uma fórmula final funerária, atendendo, inclusive, ao espaço deixado em branco; contudo, nada se poderá adiantar.

Este fragmento, nestas circunstâncias, apenas é, pois, mais um documento de aculturação linguística e estética plena. 
4 - 300/98 - Grafito de Marco Lívio Cílio [Fig. 4]

Em 1998, durante a decapagem da parte posterior oeste das termas (quadrado IV-223), ${ }^{7}$ surgiu um imbrex, partido em dois pedaços, com grafito na sua parte exterior.

Dimensões: 25,5 x 21,5/15

$\mathrm{M}(\operatorname{arci}) \cdot \operatorname{LIVI}(i) \operatorname{CILI}(i)$

De Marco Lívio Cílio

Altura das letras: 1,6 / 2,2.

ENCARNAÇÃO \& MOREIRA 2005, 133.

Caracteres actuários, gravados ainda em cru, com uma cana, cuja ponta estaria rachada (bífida), o que originou o relevo interno. Gravação à mão levantada, denotando a inclinação das letras, ora mais para trás ora mais para a frente, o jeito dado pelo escrevente. Curioso, por exemplo, o traçado do $\mathrm{M}$, claramente de cima para baixo na perna da esquerda; depois, as duas pernas do interior (como um V); finalmente, a perna da direita, em movimento de cima para baixo. Daí que o V se assemelhe a um $\mathrm{U}$ e que o $\mathrm{L}$ comece em cima por uma pequena barra, como se houvesse necessidade de marcar a altura a que se deveria começar a grafá-lo. Note-se, ainda, o cuidado posto em assinalar os vértices do primeiro I.

Tal como na inscrição de Campanus $\left(\mathrm{n}^{\circ} 5\right)$, estamos perante a identificação, aqui com os tria nomina, do proprietário do lote a entrar no forno, pois, como se disse, a gravação foi feita quando a pasta ainda se encontrava mole.

Livius é gentilício com apenas mais 5 testemunhos documentados, até ao momento, na Lusitânia (Atlas, mapa 168, p. 214), possibilitando a análise da sua distribuição a hipótese de identificar pessoas não relacionáveis com o estrato populacional pré-existente. Na verdade, tanto o personagem de Ossonoba como o de Fundão e até a Livia Libera de Viana do Alentejo se podem incluir no número dos libertos; e há um devoto da divindade Endovellicus. No aro de Mértola terá sido encontrada a estela funerária de Rustica Livi f(ilia) [IRCP 113]: a tipologia do monumento é indígena, a defunta identifica-se à maneira

7 MOREIRA 2002, 96-98 (com foto na p. 98). Interpreta-se aí o texto no nominativo.

Conimbriga, 49 (2010) 41-67 
indígena, mas o pai, assim identificado com o gentilício poderá, na verdade, pertencer também a um estrato populacional vindo de fora para a região.

Quanto ao cognomen Cilius - de que o mapa 91 do Atlas (p. 143) nos dá conta da sua distribuição dominante na área central da Lusitânia (mais de 30 testemunhos) - tem sido, porém, considerado de raiz pré-romana: Vallejo dedica-lhe várias páginas do seu livro (2005), designadamente 278-281, onde também apresenta um mapa da sua distribuição na Península Ibérica (p. 279), concluindo pela sua predominância na Lusitânia «en fórmulas onomásticas indígenas», acrescentando que Cilius «basicamente se atestigua como filiación» (p. 282).

Estaremos, pois, mui verosimilmente, perante um indígena romanizado, ou, dizendo doutro modo, mais um testemunho do estreito relacionamento entre a população indígena e a população de origem itálica.

Não há dados bastantes para se atribuir à epígrafe uma datação; contudo, se tivermos em conta a referida composição do nome, decerto se não errará se a colocarmos nos meados do século I da nossa era.

\section{5 - Grafito de Campanus [Fig. 5]}

Fragmento de imbrex, de cor vermelha e forma irregular, com grafito, encontrado durante a campanha de escavações arqueológicas de 1997, mais precisamente a 5 de Agosto, num contexto de terra castanha com telhas, materiais cerâmicos de construção e algumas pedras, no lado exterior (poente) do edifício [quadrado: I-195]. Atribuiu-se-lhe 1643/97 como $\mathrm{n}^{\circ}$. de inventário.

Dimensões: $6,5 \times 13 \times 1,8$.

CAMPANI

De Campano.

Altura das letras: 12 .

ENCARNAÇÃO 2003168 (referência); HEp 132007 nº 997; ENCARNAÇÃO \& MOREIRA 2005, 132-133.

Caracteres cursivos, gravados, provavelmente com a ponta de uma cana, na pasta ainda fresca, antes da cozedura. No primeiro A, a haste lateral direita ultrapassa o vértice superior, em jeito de lambda (uma 
tipicidade deste tipo de escrita), o mesmo acontecendo com os vértices superiores do M; P de pança 'aberta', ou seja, apenas com um traço oblíquo em vez da linha curva; segundo A de haste direita alongada para baixo; $\mathrm{N}$ bastante aberto. Todo o ductus apresenta inclinação para trás, muito nítida no traçado do I.

Este é um genitivo de posse: colocado seguramente no começo do lote que ia ao forno, significava que esse era o proprietário ou o cliente (se se preferir) - tal como hoje, nas aldeias de forno comunitário, se põe uma marca no primeiro pão do lote, para que bem se distinga.

Campanus é cognomen latino, bem atestado por Kajanto (p. 190), que documentou, no conjunto do CIL, com este nome, dois senadores, 91 homens (dos quais 11 escravos ou libertos) e 29 mulheres (das quais 2 escravas ou libertas); para este autor, o nome teve, pelo menos no início da sua utilização, o significado de habitante da Campânia. Não vamos ser taxativos em afirmar que, neste caso, estaríamos também diante de alguém vindo da Península Itálica; contudo, essa hipótese - atendendo a outros indícios da epigrafia da cidade - não será, porventura, de excluir liminarmente, até porque se trata de antropónimo frequente em torno de Emerita e com registos predominantes no litoral mediterrânico peninsular.

\section{6 - Grafito de Cimber (EBURO 383.1/06) [Fig. 6]}

Nove fragmentos de um dolium - um do bordo, seis do bojo e dois do fundo - numa camada de terra preta com carvões, pedras, material cerâmico de construção e ossos, em 17/7/2006, no quadrado I-408.

Trata-se de um dolium de bordo vertical arqueado e pança esférica (de que se nota o arranque superior), apresentando, esta, uma decoração ondulada entre duas caneluras; sobre a superior, uma outra não paralela. Sob a decoração, o grafito CIMBER (com $16 \mathrm{~cm}$ de comprimento).

Altura das letras: $\mathrm{C}=2,3 ; \mathrm{I}=3 ; \mathrm{M}=3,3 ; \mathrm{B}$ e $\mathrm{E}=4 ; \mathrm{R}=4,8$ (?).

$\mathrm{O} C$ é pequeno e aberto; $\mathrm{M}$ largo; as três últimas letras têm a haste vertical prolongada para cima, a denotar que foi a primeira a ser feita e o resto acrescentado de forma desajeitada, sem preocupações estéticas; assim, as panças do B grafaram-se com dois movimentos independentes e o R é muito cursivo.

Cimber é antropónimo latino, de que temos outro exemplo em Hornachuelos, Córdoba (Andaluzia) (registo $n^{\circ} 4350$ da base de dados epigráficos da Hispânia); ainda que a interpretação seja dubitativa, trata-se também aí de um grafito, feito em peso de tear. 
Sextus Arquius, o dedicante da pátera de prata a uma divindade indígena, quiçá Saurium (ENCARNAÇÃO 1975 270-274), cujo fundo se encontrou na Quinta do Paço (Alvarelhos, Santo Tirso), foi, hipoteticamente, identificado como CIM(bri) L(ibertus), mas constitui possibilidade a confirmar. ${ }^{8}$

Kajanto (p. 201) inclui este cognomen entre os que têm uma conotação étnica: os Cimbros, tribo germânica contra que, nos finais da República, Mário, por exemplo, teve de lutar; e mostra que não se trata de nome muito vulgar, pois que, no conjunto do CIL, apenas encontrou 15 homens com este nome e mais 8 escravos ou libertos, para além de um notável republicano, T. Annius Cimber.

A raridade deste nome na epigrafia romana peninsular e essa sua conotação étnica vêm confirmar o carácter predominantemente exógeno dos habitantes iniciais de Eburobrittium.

\section{7 - Tijolo epigrafado [Fig. 7]}

Dois fragmentos de um tijolo, ajustáveis, com inscrição feita mediante estilete rudimentar, antes da cozedura, achados aquando da decapagem do corredor das termas, em estratigrafia de derrube/ entulhamento.

Dimensões: 14,5 x 29 x 4,7.

VSQVE HIC / CCC (trecenti)

Até aqui 300 .

Altura das letras: 1. 1: 3/3,5 ( $\mathrm{V}=2,8, \mathrm{C}=2,7, \mathrm{Q}=5,5) ; 1.2: 3,2 / 3,4$.

ENCARNAÇÃO 2003 168-169; AE 2003, 857b; ENCARNAÇÃO \& MOREIRA 2005, 134; HEp 13, 2007, nº 996.

Já tivemos ocasião de fazer a análise paleográfica deste texto (art. cit., p. 134, nota 18), que ora transcrevemos:

8 Na verdade, é mui diversa - e, diga-se desde já, um tudo-nada arrevesada, pelo inusitado dos nomes e do formulário reconstituídos - a opinião de José Cardim Ribeiro, que preparou a ficha da peça no catálogo da exposição sobre as Religiões da Lusitânia (RIBEIRO 2002 p. 428-429, no 96): S(egomoni vel Sagato).ARQVI(us). CIM(ini filius) L(ucio).SAVR(io).V(otum).S(olvit).L(ibens).M(erito).//. A tradução, segundo aquele investigador, seria, pois: «A Segomo (ou a Sagatus), Arquius, filho de Cimin(i)us, por Lucius Saurius o voto cumpriu de bom grado e com razão.»

Conimbriga, 49 (2010) 41-67 
«Os caracteres estão gravados com certa graciosidade e um certo gosto até: veja-se a regularidade do S, a esbelteza do Q de longa cauda, a 'cursividade' elegante dos $\mathrm{C}$ desiguais. $\mathrm{O} \mathrm{E}$ foi grafado como dois II, o que é normal neste tipo de epígrafes. O H e o I estão certamente em nexo (a fractura na parte superior impede-nos de saber se, de facto, o I não estará no prolongamento da segunda haste do $\mathrm{H}$; o travessão cortou acentuadamente a primeira haste, o que mais nos inclina a considerar o referido nexo».

Mantemos válido o comentário publicado em 2005:

«A fim de facilitar as contagens, o operário encarregado da arrumação dos tijolos - e estamos a imaginar que o faria no solo, antes de se preparar a fornada - marcaria quantidades de tantos em tantos e essa marca iria também para o forno».

Referimo-nos, então, aos exemplos de contagens de tijolos de quadrante documentados em Conímbriga; e a apresentação desta peça no encontro de Génova, em 2001, visou concitar para ela a atenção dos investigadores, na mira de podermos contar com outros testemunhos noutras partes do mundo romano. Até este momento, e mesmo após o texto haver sido divulgado, como se vê, no AE e na HEp, não recebemos informações complementares susceptíveis de virem mostrar ser esse procedimento normal em contexto de fabrico de cerâmica utilitária. Não vamos considerar que a ausência de dados - devida, mui provavelmente, à pouca atenção que, até há poucos anos, se dava a esse tipo de cerâmica, pois não se punha a questão de ela poder ostentar grafitos com interesse histórico - seja um factor de valorização desta actividade em Eburobrittium: mas que detém um importante significado do ponto de vista económico e, até, cultural, isso detém.

\section{8 - Lucerna ${ }^{9}$ [Fig. 8]}

Fragmentos do reservatório e da base de uma lucerna, identificados em 1997, no quadrado V - 258. Tem o n ${ }^{\circ}$ de inventário: 1231-1232/97.

Diâmetro da base: $5 \mathrm{~cm}$; espessura da parede: $0,3 \mathrm{~cm}$.

9 A peça foi incluída na monografia (p. 95) e referida no trabalho escolar de Joana Filipa Rocha Gonçalves, estudante na Universidade Nova de Lisboa, sob orientação de Guilherme Cardoso, intitulado «Lucernas romanas de Eburobrittium». Retomamo-la aqui somente com a intenção de, apresentando-a novamente, alguma luz poder vir a ser lançada sobre o eventual significado da inscrição que ostenta.

Conimbriga, 49 (2010) 41-67 
De acordo com a descrição feita por Marcos Silva (1998, p. 15, $\mathrm{n}^{\circ}$ 30), que tomamos a liberdade de seguir à letra, a «pasta é beije rosada (CAILLEUX, K-91), acastanhada muito pálida, medianamente fina e dura; engobe amarelado, muito diluído e totalmente desaparecido». «Base côncava, decorada com um motivo vegetal (uma palma), circundada por duas molduras, a mais larga das quais ornada de círculos estampados (cf. ALARCÃO e PONTE, 1976, p. 82-83, Est. III, nº 17). Apresenta uma inscrição grega com o próprio molde».

A possibilidade de a inscrição estar em caracteres gregos ${ }^{10}$ foi encarada devido à primeira letra ser um E maiúsculo e haver, depois, algo semelhante a um gama seguido de I. Contudo, o signo que vem logo após esse E inicial - um círculo ovalado no sentido vertical com duas hastes oblíquas divergentes - tem paralelos nítidos com signos patentes nas estelas da chamada «escrita do Sudoeste»; poderá ser também um ómega. $\mathrm{E}$ o signo seguinte parece um $\mathrm{X}$ quase $\mathrm{V}$ ou $\mathrm{Y}$, não sendo lídimo que haja depois um gama maiúsculo e I. O que resta de seguida ainda é mais enigmático.

Por conseguinte, do ponto de vista epigráfico, apenas há a realçar que o aparecimento deste fragmento é mais um indício do 'cosmopolitismo' económico da cidade, pois estes dizeres - quer se devam filiar no grego quer na «escrita do Sudoeste»-pertencem, seguramente, a uma cultura relacionável com o Mediterrâneo.

9 - Grafito [Fig. 9]

Fragmento de imbrex, encontrado fora de contexto. Apresenta um grafito, feito com 'estilete' de ponta redonda antes da cozedura.

Dimensões: 9,5 x 16.

\section{NES V}

Altura das letras: 3,3.[S = (3), $\mathrm{V}=(3,5)]$.

$\mathrm{N}$ gravado com dois movimentos: o primeiro para as duas barras iniciais, com início e conclusão em baixo; o segundo, para traçar a haste

10 Marcos Silva chega a aproximá-la do texto patente na lucerna Q2230 do British Museum, que, em grego, significaria «A Palavra de Deus; a Graça de Deus»; esta é, porém, uma fraseologia típica já do século VI, o que, inclusive, se não coaduna com a tipologia do exemplar em estudo, atribuível - por comparação com exemplares de Conimbriga - a finais do século II ou mesmo do século III.

Conimbriga, 49 (2010) 41-67 
oblíqua da esquerda. O E foi, por seu turno, gravado em quatro tempos: primeiro a haste vertical cortada pelas três barras horizontais (a de cima não exactamente no vértice, de modo que se poderia pensar no nexo EI, que se nos figura inviável). S grafado duma só vez, de cima para baixo. O V apresenta-se em módulo maior e mais esguio, inclinado para trás.

Não há vestígios de que a inscrição seja a continuação de algo que estivesse acima nem parece que tenha tido continuidade para baixo. Desta sorte, seria aliciante ver nas três letras as siglas dos tria nomina do encomendante ou, mais provavelmente, atendendo à raridade do praenomen Numerius na epigrafia romana da Lusitânia, as três primeiras letras do seu cognomen: Nestor seria, nesse caso, uma hipótese, ainda que desse nome - próprio, aliás, pela sua conotação mitológica, de escravos e libertos - na Península Ibérica se registe apenas um testemunho mais. ${ }^{11}$ E é grande a tentação de considerar numeral (cinco) o que vem depois, eventual sinal de contagem da encomenda feita.

10 - Marca de oleiro [Fig. 10]

Fragmento de tijolo, de cor amarelada, identificado, em 1998, a norte do edifício n. ${ }^{\circ} 1$ (à entrada do campo), em terra castanha.

Dimensões: comp. 27; larg.15; esp. 6.

Dentro de um rectângulo vazado - com 11,5 x $5,5 \mathrm{~cm}$ - está nítida, em relevo, a marca do fabricante, que apresenta, como a figura mostra, uma forma inusitada, para que não encontrámos paralelos e cuja identificação com um objecto de uso quotidiano não se nos afigura verosímil. Trata-se de um logótipo (diríamos hoje...) então facilmente identificável com o proprietário do forno que preparou o tijolo, espécie de punção que também aparece no peso de tear ${ }^{12}$ achado, em 1999, no quadrado I-408 do edifício n. ${ }^{\circ} 1$, edifício datável do século I.

\section{Conclusões}

Não se encontra documentado epigraficamente, até ao momento, qual terá sido o estatuto administrativo de Eburobrittium. Faltam-nos

11 O liberto Gaius Racilius Nestor, em Belalcázar (Córdoba) - CIL II²/7, 822 = HEp 2, 1990, $300=$ AE 1987, 514.

12 Vide fig. 39, p. 74 da monografia. Reproduzimos o desenho e juntamos a foto (Fig. $\mathrm{n}^{\circ}$ 11). Tem $11 \mathrm{~cm}$ de altura, 5,3 de largura (na base) e 3,2 (no topo). $\mathrm{O}$ «campo da gravação» mede $1,9 \times 2,1$.

Conimbriga, 49 (2010) 41-67 
inscrições de monumentos públicos, blocos que houvessem sido cipos honoríficos ou pedestais de estátuas, aras a divindades clássicas ou indígenas... Não admira - que essa foi durante muito tempo e, em muitos casos, ainda é a situação de aglomerados populacionais seguramente importantes na época romana. Evoque-se o caso de Aeminium, a título de exemplo, não obstante a referida dedicatória a Constâncio Cloro, aqui também existente, cuja elevação a município se suspeita dever-se a Cláudio, atendendo às características do seu forum (CARVALHO 1998 203), mas não há qualquer informação acerca da existência de decuriões ou de duúnviros, certamente porque esses monumentos ainda se encontram embutidos nas muitas paredes da cidade medieval e moderna.

Em relação a Eburobrittium, a situação é, pois, inteiramente normal. Se a sua localização na encosta sobranceira ao vale lagunar continuou a ser predilecta mansão de privilegiados, o povo cedo terá procurado, na Idade Média, alcandorar-se, em defensiva, no morro da Óbidos actual, estrategicamente eficaz, economicamente mais propício. E, claro, dos edifícios eburobricienses foram as pedras (mesmo as que detinham letras, de significado já então obscuro, aliás) que encheram alicerces, ajudaram a subir paredes, fortificaram as muralhas... Lá se encontrarão, sem dúvida, pouco a pouco, à medida que houver remodelações ou demolições a fazer. E há que estar atento!

Apesar desse desconhecimento, os escassos monumentos epigráficos aqui estudados são, desde já, susceptíveis de dar à cidade invejável estatuto económico e social e, até, político, se tivermos em conta a dedicatória a Constâncio Cloro, o que denuncia a existência de um escol político, ainda nesse dealbar do século IV, ciente do que se passava no Império e que - como sói dizer-se - não queria deixar os seus créditos por mãos alheias e fez ouvir a sua voz, no momento oportuno, no coro de generalizado apoio ao governo central. Uma atitude que não pode deixar de ser bem salientada.

Essa relevância já vinha, porém, de longe, como tivemos ensejo de verificar: a estela relativa aos escravos, apesar da sua singeleza - ou até mesmo por isso - demonstra claramente que a cidade detinha, logo nos primórdios da sua existência, um estatuto económico tal que podia usufruir do privilégio (raro atestado epigraficamente, diga-se) de ter escravos públicos.

Por outro lado, os nomes dados a esses escravos denunciam, repita-se, um não despiciendo grau de cultura, a pôr em paralelo - sem desprimor - com cidades congéneres da Península e, até, do Império.

Conimbriga, 49 (2010) 41-67 
Suspeita-se, com razão, que o florescimento de Eburobrittium se terá devido à sua estratégica localização para intercâmbio comercial por via marítima, através do que então já seria a lagoa, ampla enseada, natural porto de abrigo para quantos passavam ou demandavam a costa ocidental peninsular, tanto numa ida para norte como para os empórios meridionais mediterrânicos. ${ }^{13}$ No entanto, os grafitos identificados na sua cerâmica, designadamente os que anunciam lotes antes de irem ao forno e, de modo especial, aquele que assinala a operação de contagem prévia, são prova cabal de uma actividade de produção cerâmica em elevada escala, não se nos afigurando ousado pensar que os destinatários não seriam apenas os habitantes da cidade e do seu ager, mas também clientes doutras paragens, para onde, por mar, se faria a exportação.

A possibilidade de os trabalhos arqueológicos prosseguirem, designadamente encosta acima, onde se encontrará boa parte do casario e também dos edifícios públicos da civitas, encara-se, pois, com o maior entusiasmo, tanto mais que começam a surgir dados sobre os seus habitantes, que, tendo demandado outras paragens, com orgulho eburobrittienses se identificavam - e isso é muito bom sinal. Estamos a recordar-nos, por exemplo, do fragmento de inscrição, eventualmente funerária, encontrado, pelos membros da Arqueohoje, nas sondagens arqueológicas levadas a efeito em Viseu, em Novembro de 2007 (se não erramos), que se refere a uma Placida - porventura pertencente à gens Turrania... - cuja origo Eburobrittiensis aí está bem expressa e por extenso.

Enfim, tudo vai, pois, no sentido de confirmar, como atrás se disse, o significativo papel que a cidade terá desempenhado ao longo de todo o Império romano, na Lusitânia ocidental. ${ }^{14}$

13 Não concordamos inteiramente com a opinião expressa por Jorge de Alarcão na 'apresentação' da monografia sobre Eburobrittium (2002, p. 7), quando afirma que «talvez o porto não tenha sido de excepcional importância, visto que Scallabis era mais facilmente abastecida por embarcações que subiam o Tejo e porque Collipo teria seu próprio porto», ainda que acrescente: «Mas algum movimento terá tido, para abastecer a cidade e as villae do seu território». O amplo e abrigado vale lagunar não terá passado despercebido aos Romanos; por outro lado, o escoamento dos produtos para o Tejo é bem provável que não se processasse por Scallabis mas por um ponto mais próximo do estuário, como se escreveu a propósito do topónimo Arruda (vide CARDOSO \& ENCARNAÇÃO 2000 e 2009).

14 Da parte de José d'Encarnação, este trabalho insere-se na investigação levada a efeito como membro do grupo Epigraphy and Iconology of Antiquity and Medieval

Conimbriga, 49 (2010) 41-67 


\section{REFERÊNCIAS BIBLIOGRÁFICAS}

ABASCAL PALAZÓN, Juan Manuel - Los Nombres Personales en las Inscripciones Latinas de Hispania, Múrcia, 1994.

$\mathrm{AE}=$ L'Année Épigraphique, Paris.

ALARCÃO, Adília Moutinho; PONTE, Salete da - «Les lampes» in ALARCÃO (J.) e ÉTIENNE (R. [dir.], Fouilles de Conimbriga - VI - Céramiques Diverses et Verres, Paris, 1976, p. 93-114, 142-150.

Atlas $=$ Milagros NAVARRO CABALLERO e José Luís RAMÍREZ SÁDABA (coord.) - Atlas Antroponímico de la Lusitania Romana, Mérida / Bordéus, 2003.

AZEVEDO, Luís Marinho de - Fundação, Antiguidades e Grandezas da Mui Insigne Cidade de Lisboa e Seus Varões Ilustres em Santidade, Armas e Letras. Catálogo de Seus Prelados e Mais Cousas Eclesiásticas e Políticas até o Ano 1147, em que foi ganhada aos Mouros por El-Rei D. Afonso Henriques, Lisboa, 1753.

CAGNAT, René - Cours d'Épigraphie Latine, Paris, ${ }^{4} 1914$.

CAILlEUX, André - Code des Couleurs des Sols, Ed. Boubée, Paris (s/d.).

CARDOSO, Guilherme; ENCARNAÇÃO, José d' - «Arruda dos Vinhos: a privileged root», Pan-european Cultural Corridors: Itineraries on Ancient Trade Roots, Valencia, 2000, 155-172.

CARDOSO, Guilherme; ENCARNAÇÃO, José d' - «Arruda dos Vinhos - Uma rota privilegiada», Boletim Cultural da Assembleia Distrital de Lisboa, 95 (IV série), 2009, 89-110. Acessível em: http://hdl.handle.net/10316/13350

CARVAlHO, Pedro C. - O Forum de Aeminium, Instituto Português de Museus, Lisboa, 1998.

CIL II = HÜBNER (Emílio) - Corpus Inscriptionum Latinarum - II, Berlim, 1869 e 1892.

$\mathrm{CIL} \mathrm{II}^{2} / 7$ = STYLOW (Armin U.) [org.] - Corpus Inscriptionum Latinarum - Conventus Cordubensis, Academia das Ciências de Berlim, 1995.

ENCARNAÇÃO, José d' - Divindades Indígenas sob o Domínio Romano em Portugal (Subsídios para o Seu Estudo), Lisboa, 1975.

ENCARNAÇÃO, José d' - «Notas sobre a epigrafia romana de Coimbra», Actas das I Jornadas do Grupo de Arqueologia e Arte do Centro, Coimbra, 1979, 171-180.

ENCARNAÇÃO, José d' - «Da imaginação e do rigor», Estudos Arqueológicos de Oeiras, 10, 2001-2002, 387-404.

ENCARNAÇÃO, José d' - «Euge, victores! Ou le culte de l'ambigüité», Serta Antiqua et Mediaevalia, VI, Roma, 2003, 167-173.

ENCARNAÇÃO, José d'; MOREIRA, José Beleza - «Epigrafia de Eburobrittium», Actas do Congresso A Presença Romana na Região Oeste, Câmara Municipal do Bombarral, 2005, 131-134.

Fouilles II = ÉTIENNE (Robert), FABRE (Georges) et LÉVÊQUE (Pierre et Monique) - Fouilles de Conimbriga, II - Épigraphie et Sculpture, Paris, 1976.

Ages, do Centro de Estudos Arqueológicos das Universidades de Coimbra e Porto (Unidade I\&D n 281 da Fundação para a Ciência e a Tecnologia).

Conimbriga, 49 (2010) 41-67 
GARCIA, Eduíno Borges - «Em busca de Eburobrittium, cidade pré-romana da Lusitânia», Actas do II Congresso Nacional de Arqueologia (Coimbra 1970). Coimbra, II, 1971, 457-462.

HEp = Hispania Epigraphica, Madrid.

IRCP = ENCARNAÇÃO (José d') - Inscrições Romanas do Conventus Pacensis Subsídios para o Estudo da Romanização, Coimbra, 1984.

KAJANTO, Iiro - The Latin Cognomina, Roma, 1982 (reimp.).

MANTAS, Vasco Gil - «Inscrições romanas do Museu Municipal de Torres Vedras», Conimbriga 211982 5-99.

MOREIRA, José Beleza - A Cidade Romana de Eburobrittium - Óbidos, Porto, 2002. [Veja-se também recensão, de Vasco MANTAS, in Conimbriga 422003 248-254].

SÁ, Ana Marques de - Civitas Igaeditanorum: Os Deuses e os Homens, Idanha-a-Nova, 2007.

RIBEIRO, José Cardim (coord.) - Religiões da Lusitânia - Loquuntur Saxa. Lisboa, 2002.

SILVA, Marcos Daniel Osório da - Lucernas de Eburobrittium, trabalho inédito, feito, em 1998, no âmbito do Mestrado de Arqueologia, Faculdade de Letras de Coimbra.

SOLIN, Heikki - Die griechischen Personennamen in Rom. Ein Namenbuch, 1, Berlin-Nova Iorque, 1982.

TURCAN, Robert - «Le culte impérial au $\mathrm{III}^{\mathrm{e}}$ siècle», Aufstieg und Niedergang der Römischen Welt 216.21978 996-1084.

VALLEJO RUIZ, José María - Antroponimia Indígena de la Lusitania Romana, Vitoria-Gasteiz, 2005.

Conimbriga, 49 (2010) 41-67 


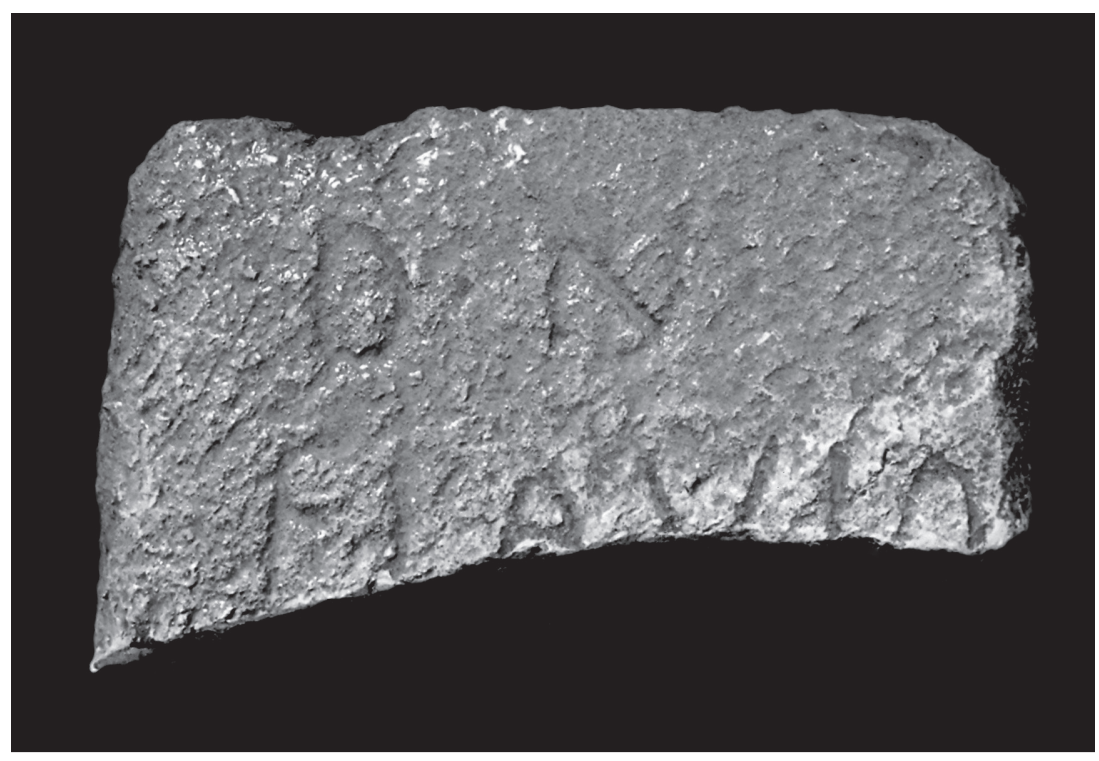

FIG. 1

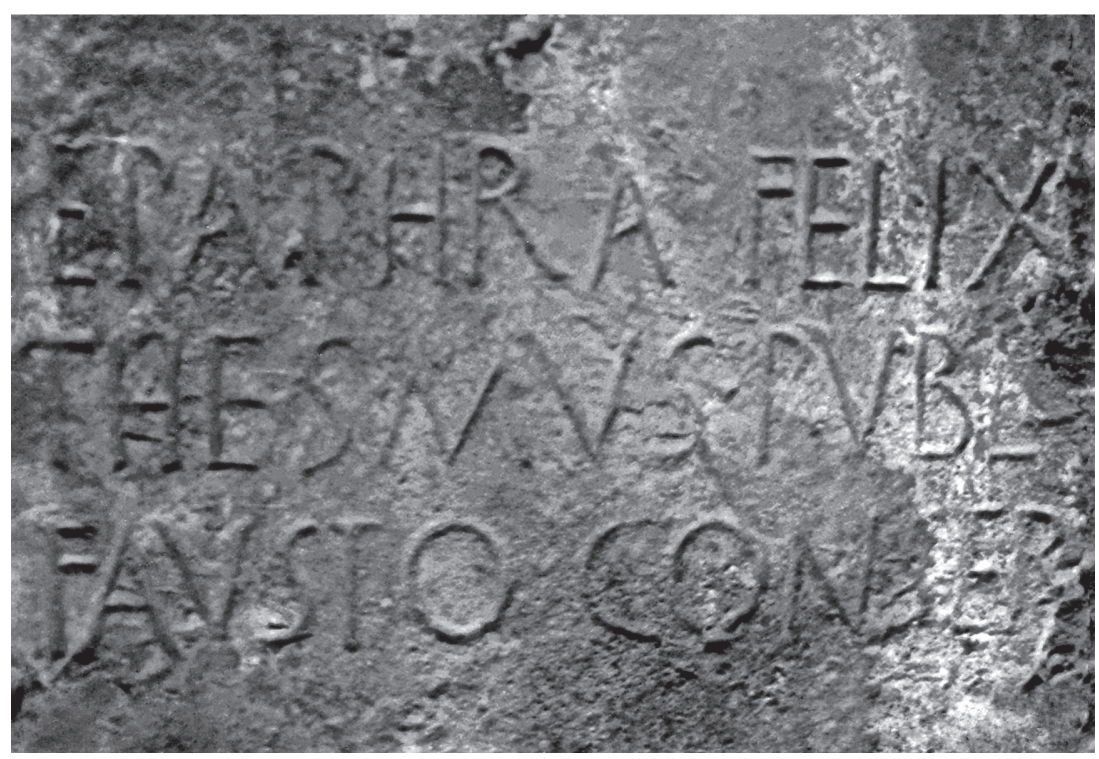

FIG. 2a 

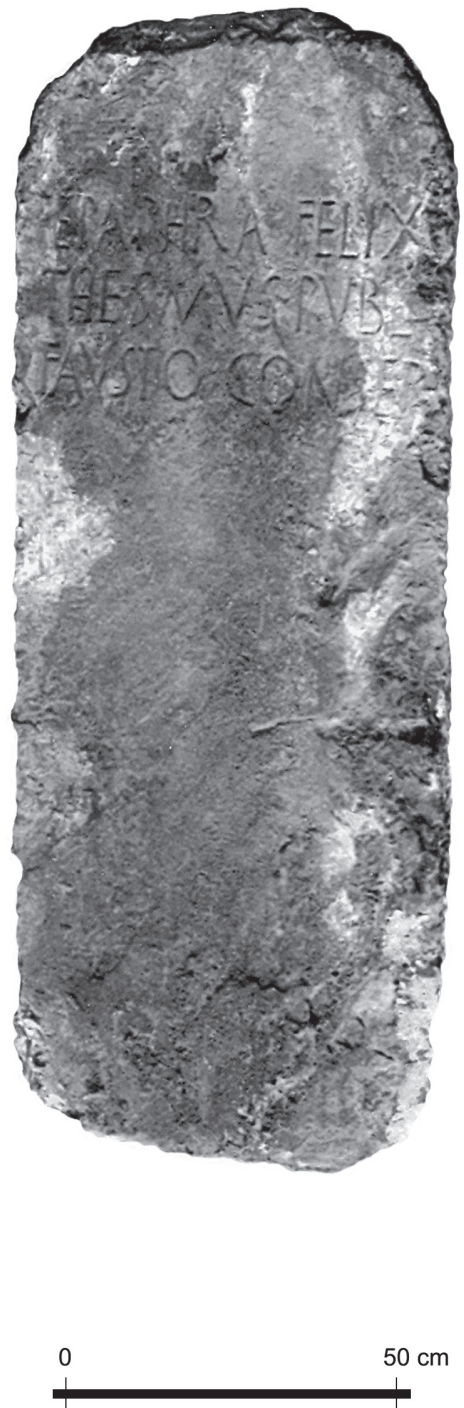

FIG. 2b 


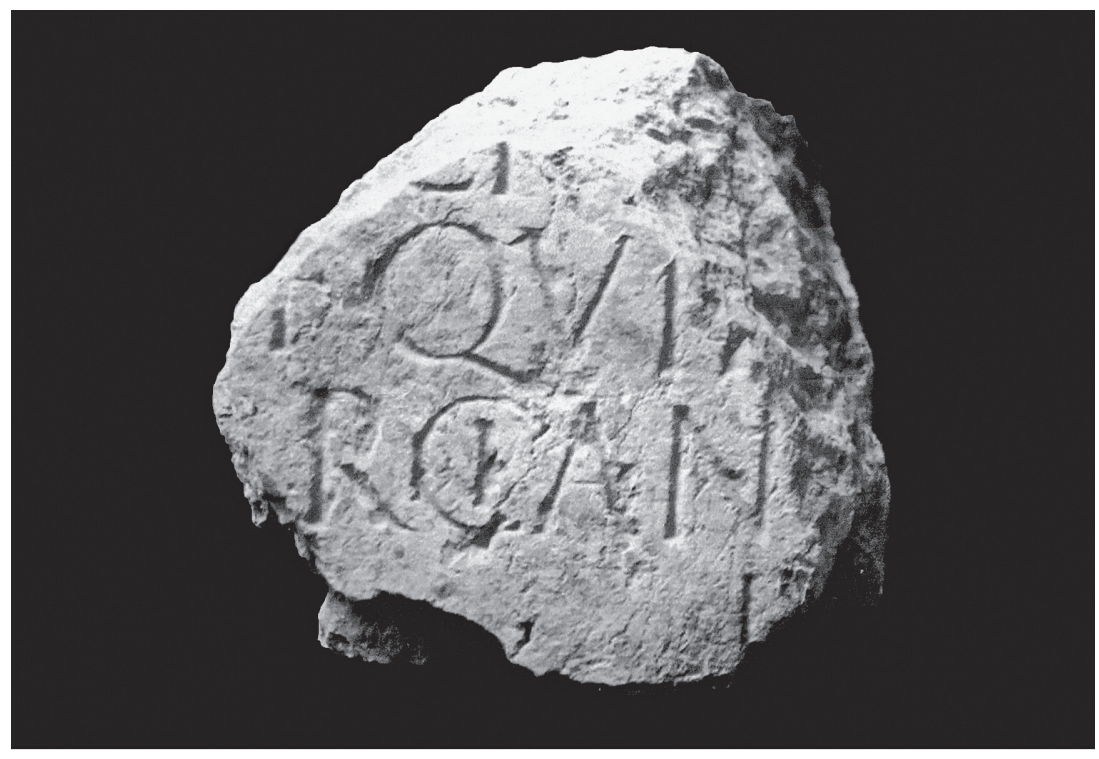

FIG. 3

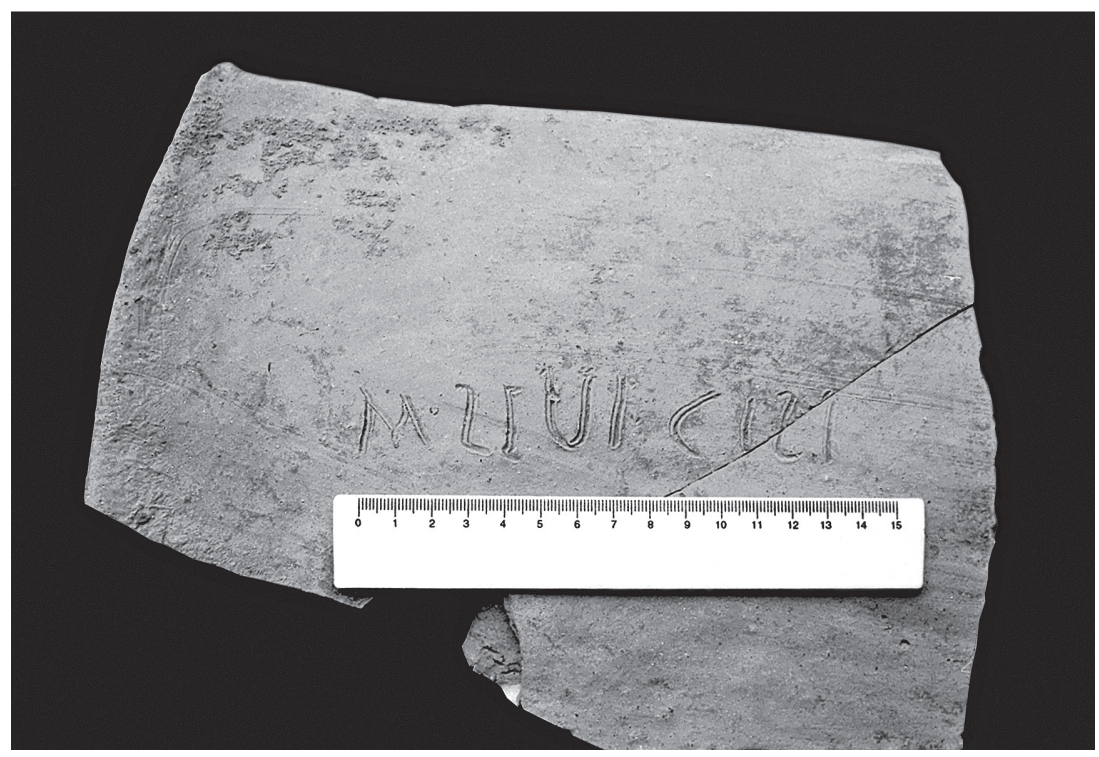

FIG. 4 


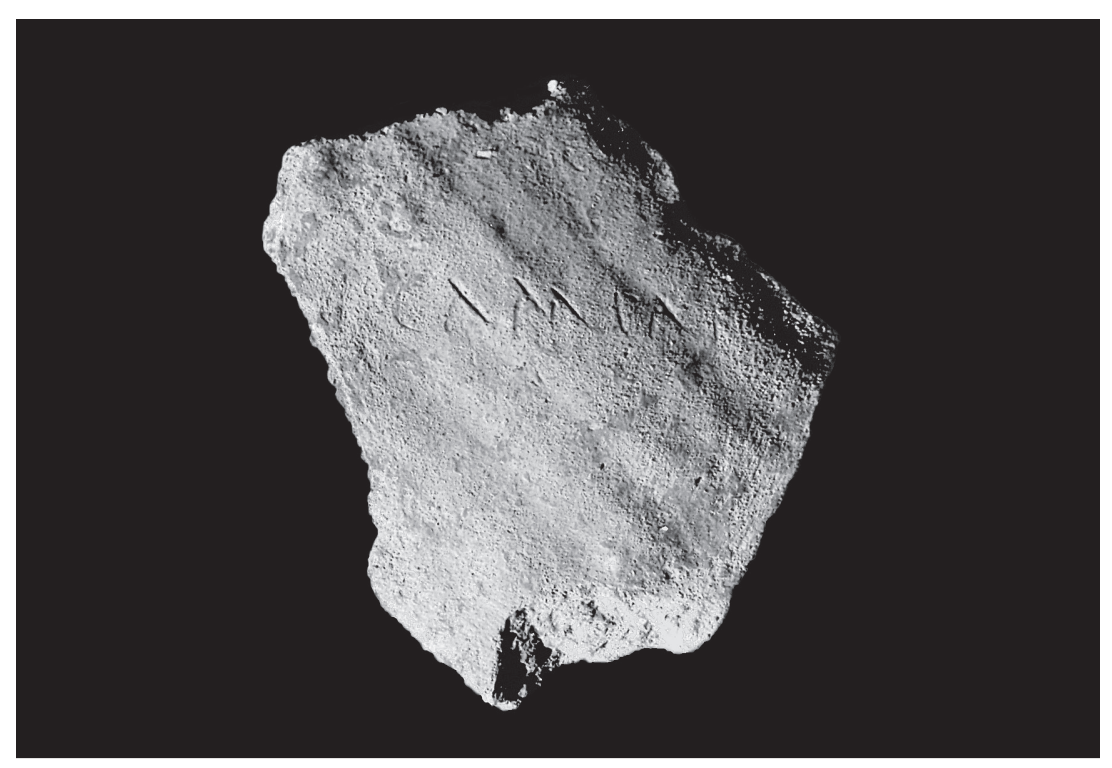

FIG. 5

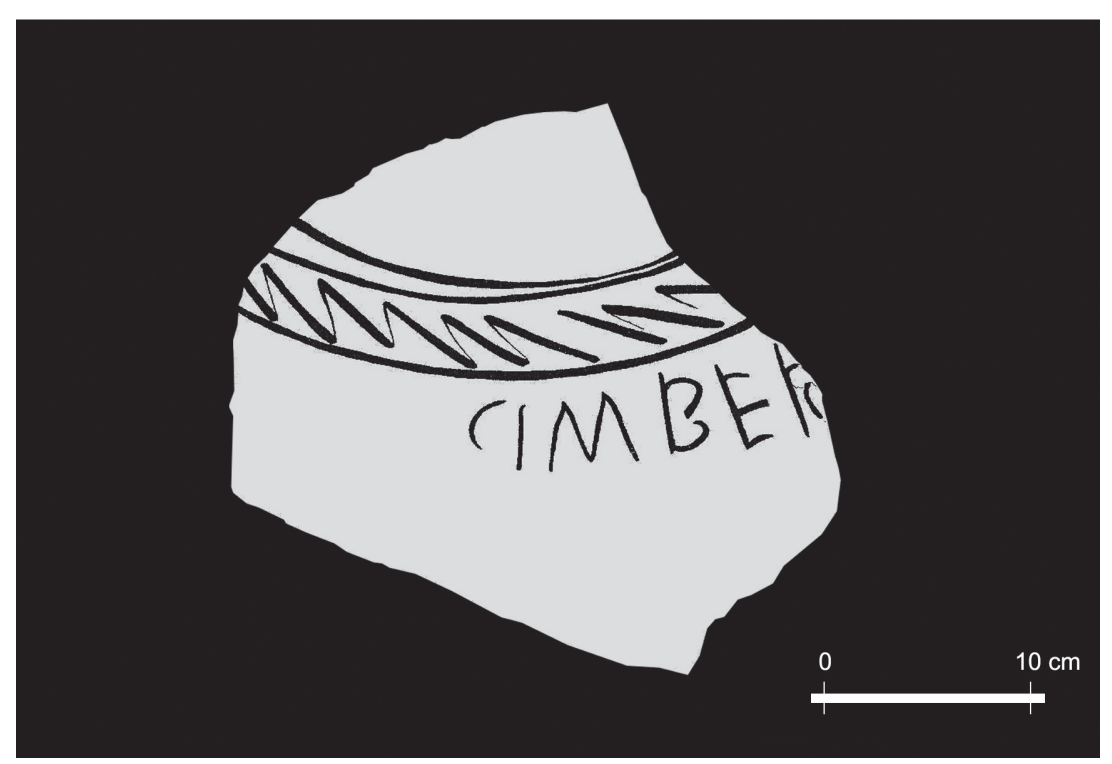

FIG. 6 


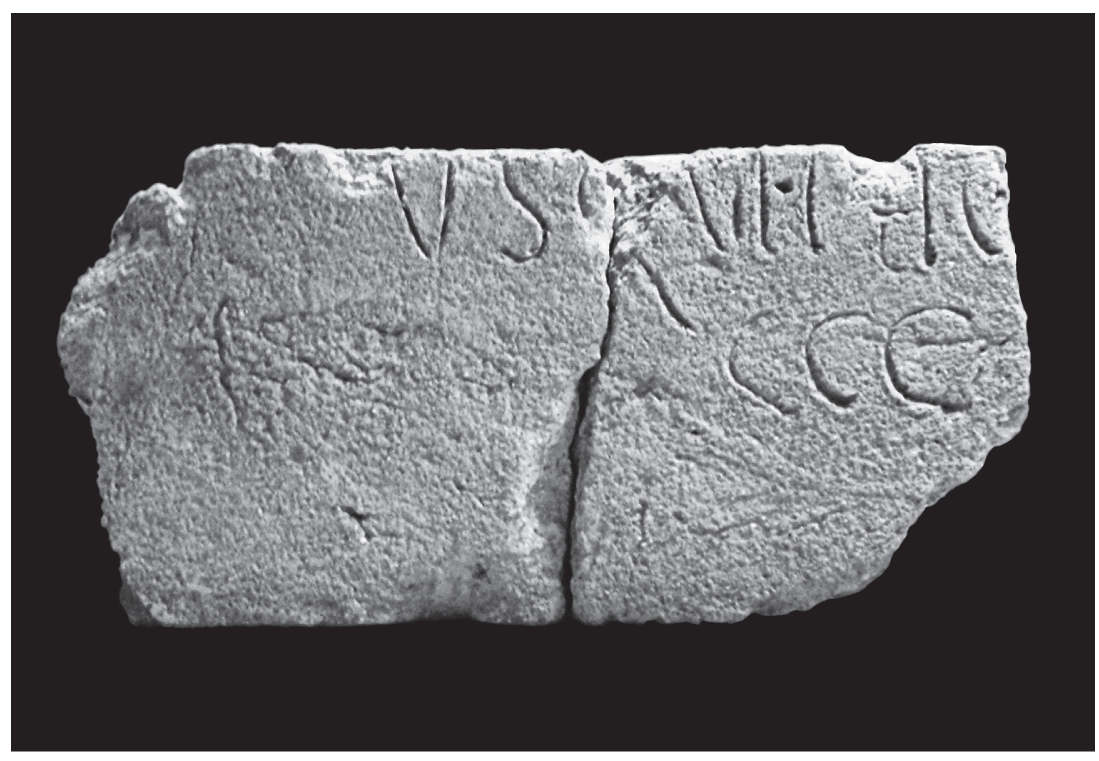

FIG. 7

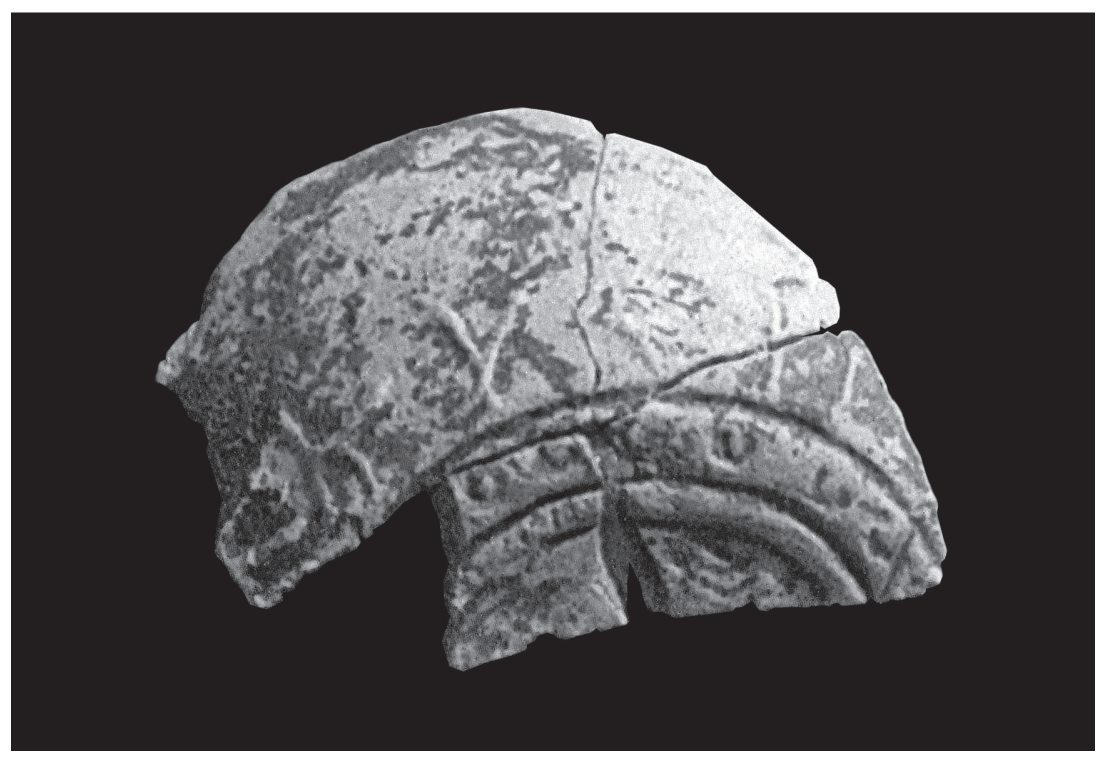

FIG. 8 


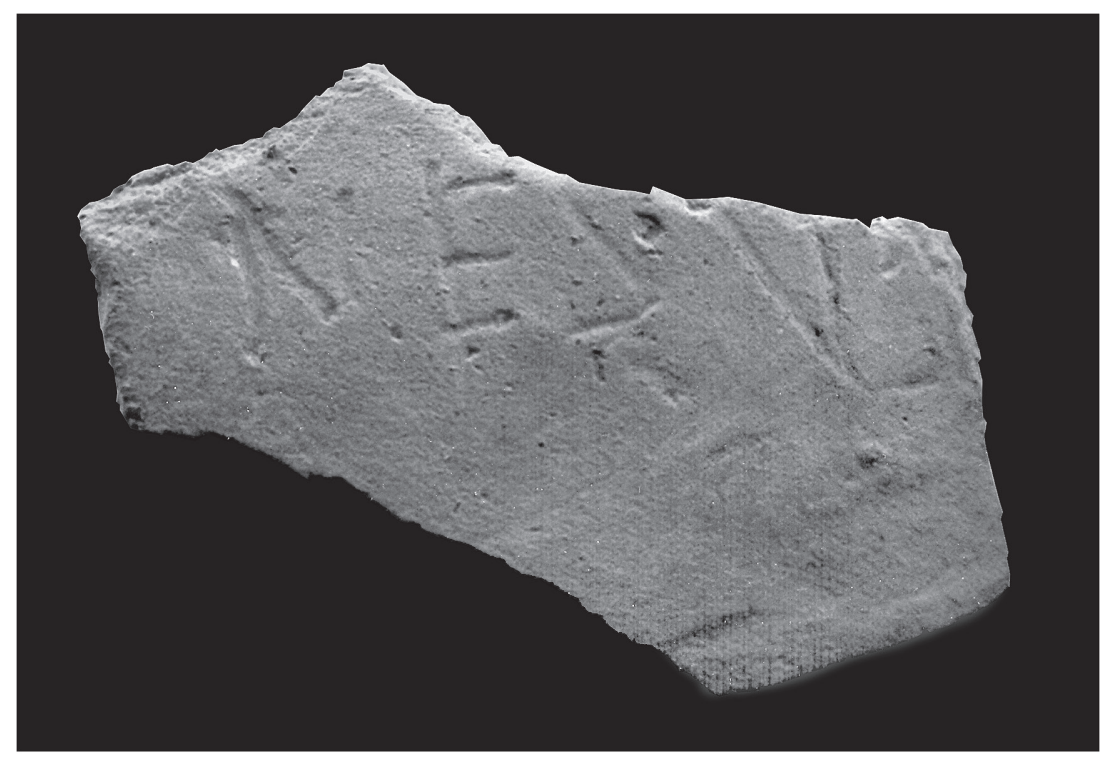

FIG. 9

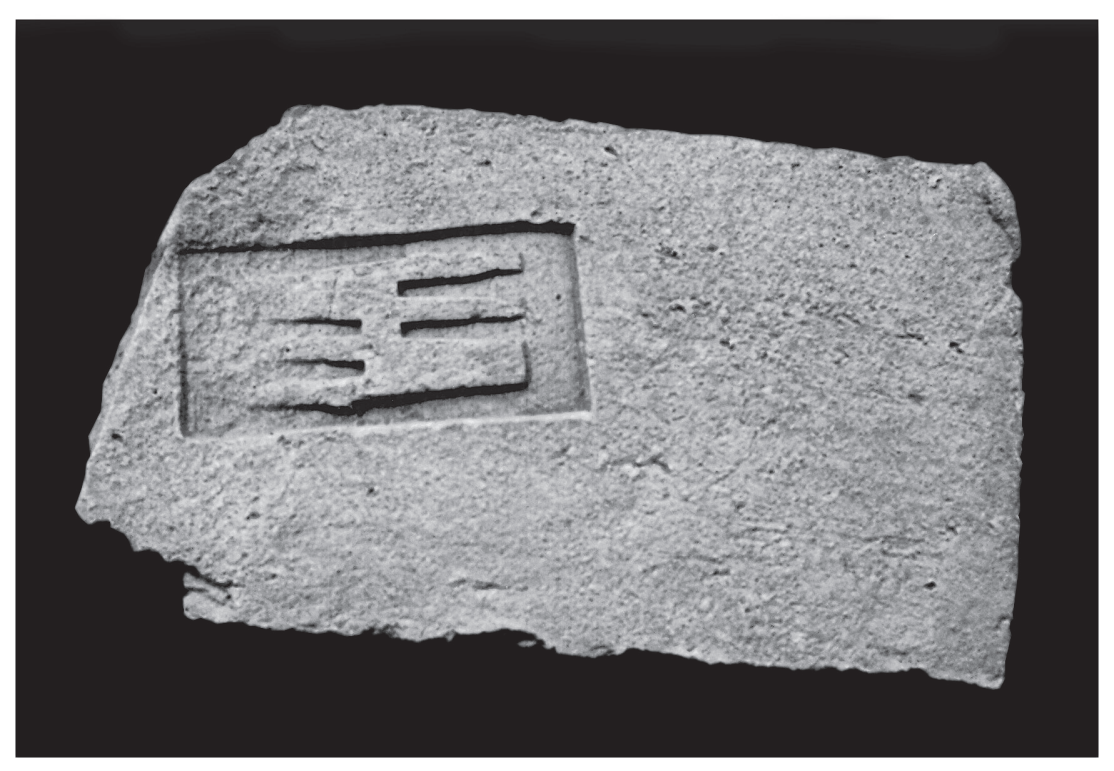

FIG. 10 


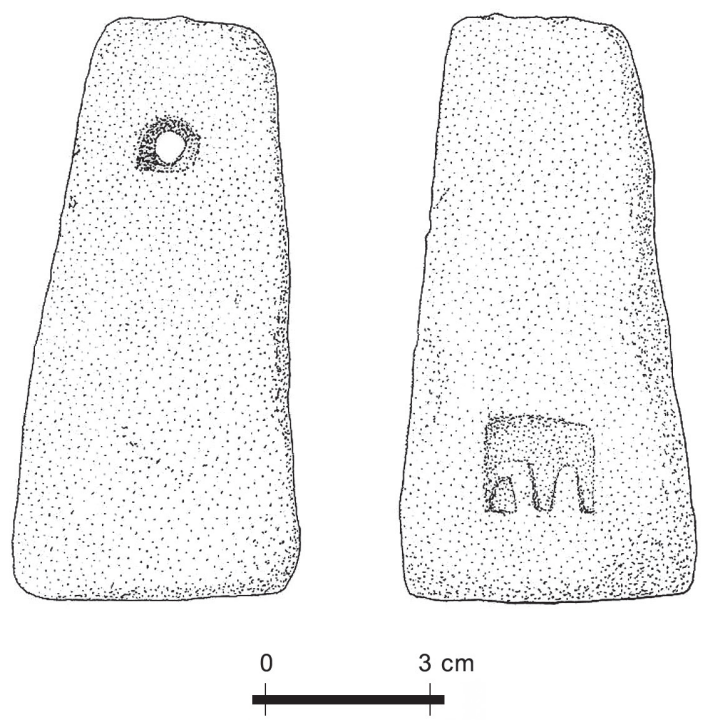

FIG. 11

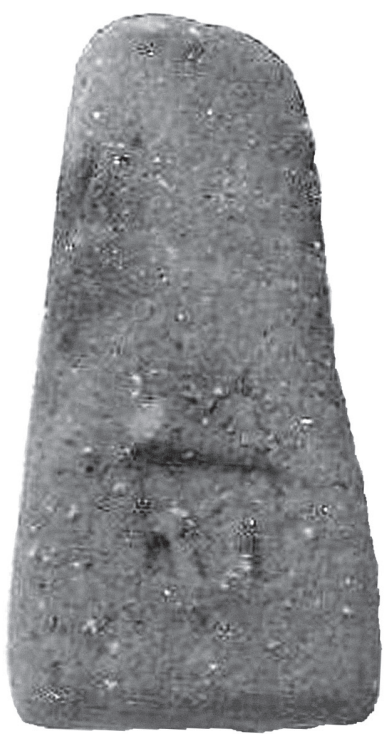

FIG. 11a 